\title{
RELATION OF TOXIC REACTIONS IN GOLD THERAPY TO IMPROVEMENT IN RHEUMATOID ARTHRITIS
}

\author{
A REPORT
}

\author{
BY \\ THE RESEARCH SUB-COMMITTEE* OF THE EMPIRE \\ RHEUMATISM COUNCIL
}

\section{Introduction}

It is a common belief that those patients who develop toxic reactions during gold therapy enjoy some measure of remission of their rheumatoid arthritis more frequently as a consequence. Confirmation of this belief has been sought in the records of the Gold Trial recorded on p. 315 of this issue of the Annals of the Rheumatic Diseases.

\section{Data and Method}

The problem posed was whether the condition of patients with rheumatoid arthritis who developed toxic symptoms during a 5-month course of gold therapy"the toxic group"-improved more (or less) than those who remained free from such symptoms-"the non-toxic group".

In the preceding report (see p. 315 above) it was shown that 35 of a series of 99 patients treated with $1 \mathrm{~g}$. gold, and 16 of a series of 100 patients treated with $0.01 \mathrm{mg}$. gold, hereinafter referred to as the controls, experienced at least one toxic reaction. With but one exception (thrombocytopenic purpura in the 12th month), all the reactions occurred during the period in which the injections were given, i.e. the first 5 months of the trial.

77 of the gold series ( 31 toxic, 46 non-toxic) and 82 of the controls (12 toxic, 70 non-toxic) were followed for $\mathbf{3 0}$ months from the start of the trial, and this supplementary report compares the progress during this period of the toxic and non-toxic sub-groups of the gold and control series.

The toxic groups were sub-divided into "severe" and "less severe", the former comprising patients with dermatitis (gold 18, controls 6) and purpura (gold 2, controls 1).

- For particulars of membership of this sub-committee, see p. 315.
This classification of the gold and control series may be summarized as follows:

\begin{tabular}{|c|c|c|c|c|c|c|c|}
\hline Series & .. & .. & . & Gold & & Cont & \\
\hline \multirow{4}{*}{ Group } & \multirow{3}{*}{ Toxic } & \multirow{2}{*}{ Severe } & Dermatitis & \multirow{2}{*}{20} & \multirow{3}{*}{31} & \multirow{2}{*}{$\left.\frac{6}{1}\right\}$} & \multirow{3}{*}{12} \\
\hline & & & Purpura & & & & \\
\hline & & \multicolumn{2}{|c|}{ Less Severe } & 11 & & & \\
\hline & \multicolumn{3}{|c|}{ Non-Toxic } & & 46 & & 70 \\
\hline & \multicolumn{2}{|c|}{ Total } & . & & 77 & & 82 \\
\hline
\end{tabular}

Table I (overleaf) shows that at the start of the trial the toxic and non-toxic groups did not differ materially as regards sex, age, duration of symptoms, or type of onset of disease. As will appear, they were also similar initially as regards all the indices of assessment.

Since, by most of the indices, the advantage to the gold series was at its peak at the 12-month assessment (i.e. 6 months after the completion of the injections), one would expect that any difference between the toxic and non-toxic groups would be most evident at this point, at least in the gold-treated patients.

Attention was therefore concentrated mainly on a comparison of the toxic and non-toxic groups at the 12-month assessment, although for most of the indices comparison was also made at Month 18 and Month 30.

\section{Results}

Functional Capacity (Physician's Estimate) (Table II, overleaf)

The distributions of patients in the five grades showed no significant differences between the toxic and non-toxic groups, or between the severe and less severe toxic groups, either at Month 0 or at Month 12. 
TABLE I

COMPARISON OF THE TOXIC AND NON-TOXIC GROUPS AT THE START OF THE TRIAL

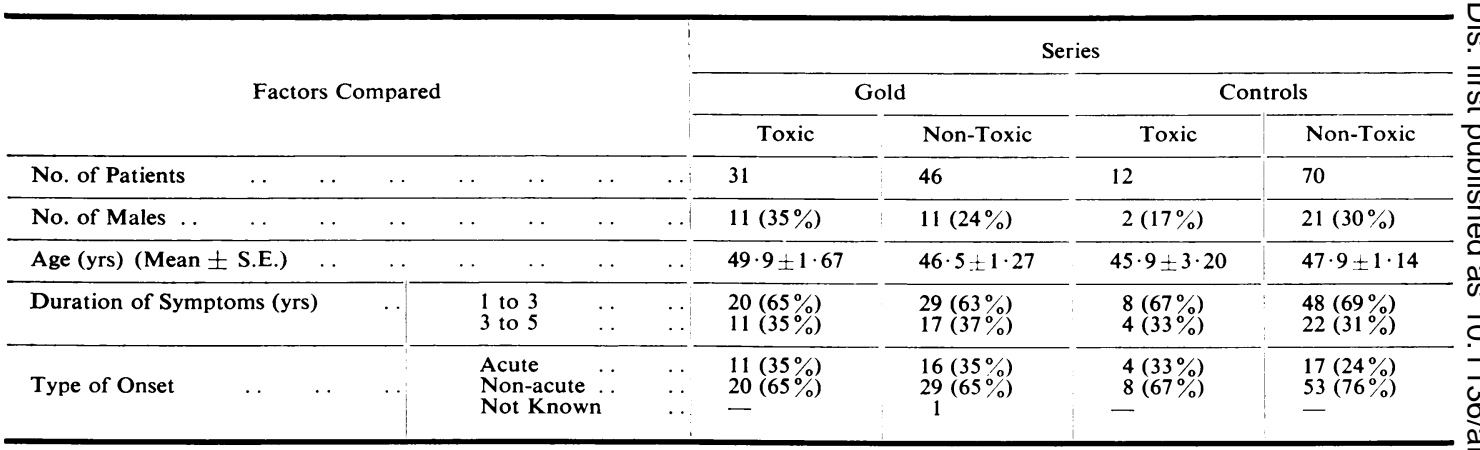

The percentages in the two best grades, taken together because of the small number of cases involved, are shown in Table II. In the gold series, at the start, 68 per cent. of the toxic, but only 59 per cent. of the non-toxic group were in these grades at the initial assessment. By Month 12, the percentages were equal ( 87 per cent.), so that a higher proportion of the non-toxic cases had moved into them. At Month 18, there was a slight but non-significant advantage to the non-toxic group, and at Month 30, no difference. In the control series, the seven patients in the severe toxic group did relatively badly.

TABLE II

PERCENTAGE OF PATIENTS IN THE HIGHEST FUNCTIONAL CAPACITY GRADES (1 AND 2) IN THE TOXIC AND NON-TOXIC GROUPS

\begin{tabular}{|c|c|c|c|c|c|c|c|}
\hline \multirow{2}{*}{ Series } & \multirow{2}{*}{\multicolumn{2}{|c|}{ Group }} & \multirow{2}{*}{$\begin{array}{c}\text { No. } \\
\text { of } \\
\text { Patients }\end{array}$} & \multicolumn{2}{|c|}{ Months from } & \multicolumn{2}{|c|}{ Start of Trial } \\
\hline & & & & 0 & 12 & 18 & 30 \\
\hline \multirow{3}{*}{ Gold .. } & \multicolumn{2}{|c|}{ Non-Toxic . } & 46 & 59 & 87 & 89 & 83 \\
\hline & \multirow{2}{*}{ Toxic } & Total & 31 & 68 & 87 & 81 & 84 \\
\hline & & $\begin{array}{l}\text { Severe } \\
\text { Less Severe }\end{array}$ & $\begin{array}{l}20 \\
11\end{array}$ & $\begin{array}{l}75 \\
55\end{array}$ & $\begin{array}{l}95 \\
73\end{array}$ & $\begin{array}{l}90 \\
64\end{array}$ & $\begin{array}{l}80 \\
91\end{array}$ \\
\hline \multirow{3}{*}{ Control } & \multicolumn{2}{|c|}{ Non-Toxic } & 70 & 67 & 83 & 79 & 77 \\
\hline & \multirow{2}{*}{ Toxic } & Total & 12 & 92 & 75 & 75 & 75 \\
\hline & & $\begin{array}{l}\text { Severe } \\
\text { Less Severe }\end{array}$ & $\begin{array}{l}7 \\
5\end{array}$ & $\begin{array}{r}86 \\
100\end{array}$ & $\begin{array}{r}57 \\
100\end{array}$ & $\begin{array}{r}57 \\
100\end{array}$ & $\begin{array}{r}57 \\
100\end{array}$ \\
\hline
\end{tabular}

Patient's Estimate of Fitness (Tables III and IV)

These tabulations suggest that patients who developed toxicity on gold were on the average slightly more "fit" at the outset, but the differences were not significant. In the controls this suggestion did not hold good.

At Month 12, the differences in the mean grades were less pronounced (Table III) and a higher proportion of the non-toxic group had become "75 per cent. or more fit" (Table IV). Indeed, in the gold series, there were 44 per cent. more at this level of fitness in the non-toxic group at Month 12 i than at Month 0, as against 29 per cent. more in the toxic group.

Within the toxic group the figures suggest that $\mathrm{W}$ those with severe symptoms did slightly better than 의 those with less severe symptoms.

At 30 months, only 71 per cent. of the toxic group on gold felt " 75 per cent. or more fit" as

TABLE III

MEAN GRADES OF PATIENT'S ESTIMATE OF FITNESS IN THE TOXIC AND NON-TOXIC GROUPS

\begin{tabular}{|c|c|c|c|c|c|c|}
\hline \multirow[t]{2}{*}{ Series } & \multirow{2}{*}{\multicolumn{2}{|c|}{ Group }} & \multirow{2}{*}{$\begin{array}{c}\text { No. } \\
\text { of } \\
\text { Patients }\end{array}$} & \multicolumn{2}{|c|}{$\begin{array}{l}\text { Mean Grade } \\
\text { (as percentage of } \\
\text { complete fitness) }\end{array}$} & \\
\hline & & & & Month 0 & Month 12 & \\
\hline \multirow{3}{*}{ Gold } & \multicolumn{2}{|c|}{ Non-Toxic . . } & 46 & 57 & 75 & \\
\hline & \multirow{2}{*}{ Toxic } & Total & 31 & 65 & 73 & \\
\hline & & $\begin{array}{l}\text { Severe } \\
\text { Less Severe }\end{array}$ & $\begin{array}{l}20 \\
11\end{array}$ & $\begin{array}{l}67 \\
61\end{array}$ & $\begin{array}{l}81 \\
63\end{array}$ & \\
\hline \multirow{3}{*}{ Control } & \multicolumn{2}{|c|}{ Non-Toxic } & 70 & 61 & 71 & \\
\hline & \multirow{2}{*}{ Toxic } & Total & 12 & 58 & 70 & \\
\hline & & $\begin{array}{l}\text { Severe } \\
\text { Less Severe }\end{array}$ & $\begin{array}{l}7 \\
5\end{array}$ & $\begin{array}{l}59 \\
58\end{array}$ & $\begin{array}{l}65 \\
85\end{array}$ & \\
\hline
\end{tabular}

PERCENTAGE OF PATIENTS WHO FELT "75 PER CENT. $\frac{\mathrm{O}}{3}$ OR MORE FIT" IN THE TOXIC AND NON-TOXIC GROUPS

\begin{tabular}{|c|c|c|c|c|c|c|c|}
\hline \multirow{2}{*}{ Series } & \multirow{2}{*}{\multicolumn{2}{|c|}{ Group }} & \multirow{2}{*}{$\begin{array}{c}\text { No. } \\
\text { of } \\
\text { Patients }\end{array}$} & \multicolumn{4}{|c|}{ Months from Start of Trial } \\
\hline & & & & 0 & 12 & 18 & 30 \\
\hline \multirow{3}{*}{ Gold ... } & \multicolumn{2}{|c|}{ Non-Toxic .. } & 46 & 41 & 85 & 76 & 78 \\
\hline & \multirow{2}{*}{ Toxic } & Total & 31 & 52 & 81 & 81 & 71 \\
\hline & & $\begin{array}{l}\text { Severe } \\
\text { Less Severe }\end{array}$ & $\begin{array}{l}20 \\
11\end{array}$ & $\begin{array}{l}60 \\
36\end{array}$ & $\begin{array}{l}90 \\
64\end{array}$ & $\begin{array}{l}95 \\
55\end{array}$ & $\begin{array}{l}70 \\
73\end{array}$ \\
\hline \multirow{3}{*}{ Control } & \multicolumn{2}{|c|}{ Non-Toxic . . } & 70 & 49 & 79 & 71 & 76 \\
\hline & \multirow{2}{*}{ Toxic } & Total & 12 & 33 & 75 & 75 & 83 \\
\hline & & $\begin{array}{l}\text { Severe } \\
\text { Less Severe }\end{array}$ & $\begin{array}{l}7 \\
5\end{array}$ & $\begin{array}{l}27 \\
40\end{array}$ & $\begin{array}{l}71 \\
80\end{array}$ & $\begin{array}{l}71 \\
80\end{array}$ & $\begin{array}{l}86 \\
80\end{array}$ \\
\hline
\end{tabular}


against 78 per cent. of the non-toxic group on gold, and there was no difference between the severe and less severe sub-groups in this respect at this final point. In the control series these slight differences were reversed.

\section{Joints Affected (Table V)}

At Month 0 there was no real difference between the toxic and non-toxic groups, but by Month 12 the non-toxic group showed the greater improvement. Even among the small numbers involved, there was a significant difference between the non-toxic and toxic patients in the gold series as regards the mean number of joints affected at this point (non-toxic $5 \cdot 5$ and toxic $9 \cdot 2$ per patient).

If the initial level for each group is taken as 100 per cent. (right-hand section of Table V), then the number of joints affected in the non-toxic group at 12 months was reduced to 33 per cent. of the initial level, but in the toxic group to only 49 per cent. Subsequently, the number of joints affected increased in about the same proportion in both series.

Between the severe and less severe toxic groups, no significant differences could be demonstrated from these data.

In the control series, the non-toxic patients showed consistently greater improvement at every assessment than the toxic patients.

\section{Strength of Grip (Table VI, overleaf)}

The differences in the mean strength of either the right or the left grip at the start of the trial between the toxic and non-toxic groups were not statistically significant, but the strength of the left grip in the less severe toxic group in the gold series was significantly lower than that in the severe toxic group (Table VI).
Taking the mean of each group at Month 0 as 100, it is seen that the toxic group certainly did not improve more than the non-toxic group. Indeed, whilst the non-toxic group in the gold series improved the right grip by 25 per cent., and the left grip by 26 per cent. at 12 months, the toxic group improved by only 13 and 17 per cent. for the right and left grips respectively. Nor was there any real difference between the severe and less severe toxic patients in this respect. If anything, the patients with less severe toxicity fared better as regards the left grip.

As one would expect, no consistent pattern emerged in the control series.

\section{Haemoglobin Concentration, Erythrocyte Sedimen- tation Rate, and Consumption of Analgesic Tablets}

No Tables are presented for these indices, since the results were very similar to those already discussed.

Briefly, the toxic and non-toxic groups were similar at the outset as regards all these indices.

The haemoglobin levels of both the toxic and the non-toxic groups improved by 8 per cent. by Month 12 , after which the mean concentration gradually fell again; only in the severe toxic group of the gold series was the level at Month 30 significantly below the peak figure at Month 12 .

The erythrocyte sedimentation rate fell by Month 12 to 51 per cent. of the initial level in the non-toxic group, and to 56 per cent. in the toxic group; it then increased again but to a slightly greater extent in the toxic group.

The average number of analgesic tablets taken per patient per diem was the same for the non-toxic and toxic groups at every assessment.

TABLE V

MEAN NUMBER OF JOINTS AFFECTED (PER PATIENT) IN THE TOXIC AND NON-TOXIC GROUPS

\begin{tabular}{|c|c|c|c|c|c|c|c|c|c|c|c|}
\hline \multirow{3}{*}{\multicolumn{2}{|c|}{ Series }} & & \multirow{3}{*}{$\begin{array}{l}\text { Month of } \\
\text { Assessment }\end{array}$} & \multicolumn{4}{|c|}{$\begin{array}{l}\text { Mean Number of Joints Affected } \\
\text { (per patient) }\end{array}$} & \multicolumn{4}{|c|}{ Trend } \\
\hline & & & & \multirow{2}{*}{$\begin{array}{l}\text { Non- } \\
\text { Toxic }\end{array}$} & \multicolumn{3}{|c|}{ Toxic } & \multirow{2}{*}{$\begin{array}{l}\text { Non- } \\
\text { Toxic }\end{array}$} & \multicolumn{3}{|c|}{ Toxic } \\
\hline & & & & & Total & Severe & $\begin{array}{l}\text { Less } \\
\text { Severe }\end{array}$ & & Total & Severe & $\begin{array}{l}\text { Less } \\
\text { Severe }\end{array}$ \\
\hline Gold & $\cdots$ &. & $\begin{array}{c}0 \\
12 \\
18 \\
30 \\
\text { No. of Patients }\end{array}$ & $\begin{array}{r}16 \cdot 7 \\
5 \cdot 5 \\
6 \cdot 4 \\
7 \cdot 6 \\
46\end{array}$ & $\begin{array}{r}18 \cdot 9 \\
9 \cdot 2 \\
9 \cdot 6 \\
10 \cdot 6 \\
31\end{array}$ & $\begin{array}{r}18 \cdot 7 \\
8 \cdot 8 \\
9 \cdot 2 \\
11 \cdot 3 \\
20\end{array}$ & $\begin{array}{r}19 \cdot 3 \\
9 \cdot 9 \\
10 \cdot 2 \\
9 \cdot 3 \\
11\end{array}$ & $\begin{array}{r}100 \\
33 \\
38 \\
46\end{array}$ & $\begin{array}{r}100 \\
49 \\
51 \\
56\end{array}$ & $\begin{array}{r}100 \\
47 \\
49 \\
60\end{array}$ & $\begin{array}{r}100 \\
51 \\
53 \\
48\end{array}$ \\
\hline \multirow[t]{2}{*}{ Controls } & \multirow[t]{2}{*}{. } & \multirow[t]{2}{*}{$\cdots$} & $\begin{array}{r}0 \\
12 \\
18 \\
30\end{array}$ & $\begin{array}{l}18 \cdot 5 \\
11 \cdot 2 \\
11 \cdot 5 \\
10 \cdot 3\end{array}$ & $\begin{array}{l}16 \cdot 6 \\
15 \cdot 2 \\
14 \cdot 3 \\
13 \cdot 0\end{array}$ & $\begin{array}{r}13 \cdot 3 \\
15 \cdot 1 \\
12 \cdot 3 \\
8 \cdot 6\end{array}$ & $\begin{array}{l}21 \cdot 2 \\
15 \cdot 2 \\
17 \cdot 2 \\
19 \cdot 2\end{array}$ & $\begin{array}{r}100 \\
61 \\
62 \\
56\end{array}$ & $\begin{array}{r}100 \\
92 \\
86 \\
78\end{array}$ & $\begin{array}{r}100 \\
114 \\
92 \\
65\end{array}$ & $\begin{array}{r}100 \\
72 \\
81 \\
91\end{array}$ \\
\hline & & & No. of Patients & 70 & 12 & 7 & 5 & & & & \\
\hline
\end{tabular}

$\mathbf{S}=$ Significant difference between the toxic and non-toxic groups. 
TABLE VI

MEAN STRENGTH OF GRIP (mm. Hg) COMPARISON OF TOXIC AND NON-TOXIC GROUPS AT MONTHS 0, 12, 18, AND 30

(Mean Grip at Month 0 in Each Group $=100$ )

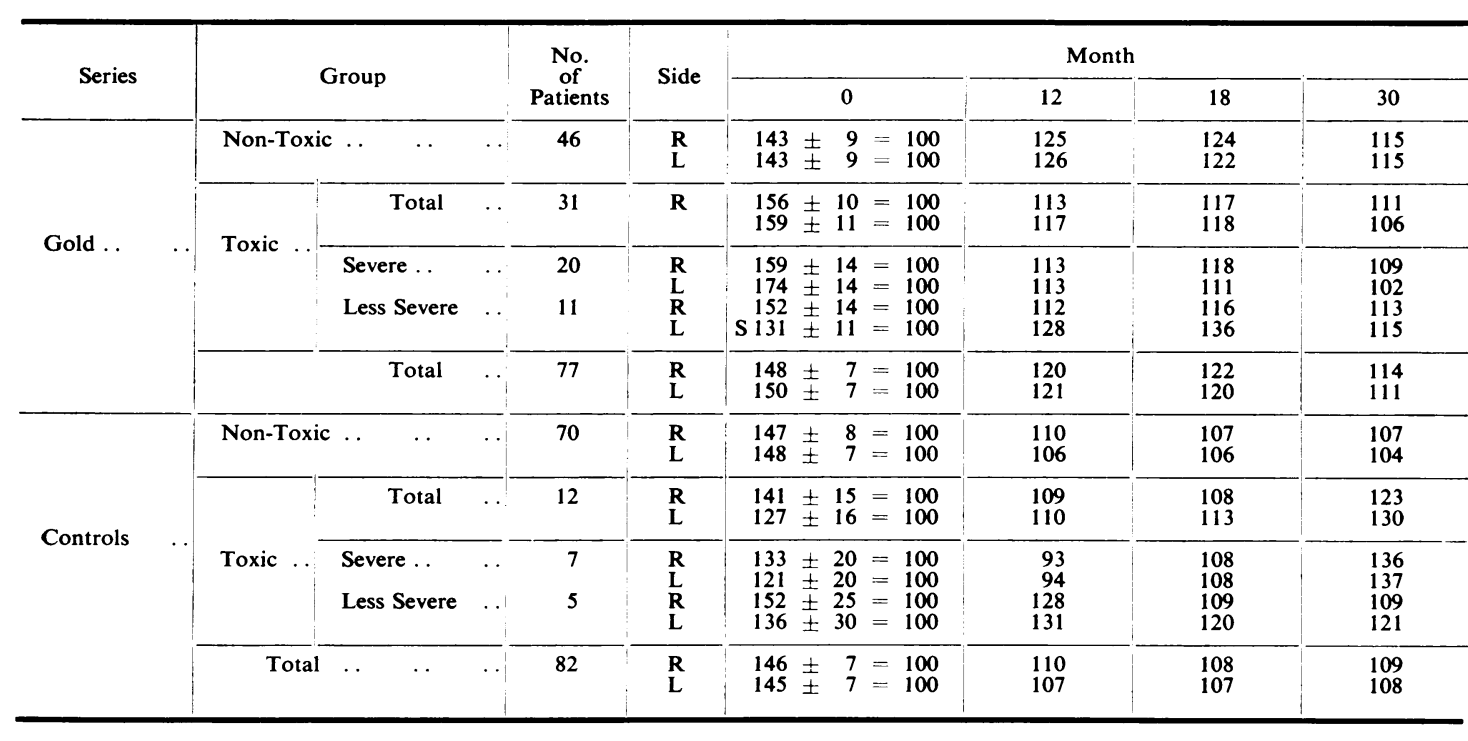

\section{Sheep Cell Agglutination Test}

No comparison of the toxicity groups in the gold series by this index was possible, because only twenty of the 46 non-toxic patients and eighteen of the 31 toxic patients were tested at both Month 0 and Month 12.

\section{Radiological Findings (Tables VII and VIII, opposite)}

At the start of the trial the number of joints (per person) affected in any way varied only between an average of 6 and 7 per patient in the different groups. The mean number of joints which were narrowed was either two or three per patient-if we exclude the two very small control sub-groups (Table VII). Similarly, the mean number of erosions present varied only between 6 and 7 per person. No differences between the non-toxic and toxic groups or between the severe and less severe toxic groups existed therefore at the outset.

Radiological progression in the hands was measured by:

(a) The number of joints which narrowed, as a percentage of the number which could narrow (i.e. not initially narrowed);

(b) The mean number of new erosions-per assessable joint; (c) The mean number of extensions of old erosion - per assessable joint.

Details of the methods of computation were given in the preceding Report. To reduce the tabulations it was considered sufficient to compare the toxicity groups by these three indices for the $\overrightarrow{\bar{a}}$ first period (0-18 months) and for the whole period (0-30 months) (Table VIII).

In the event (as the Tables show) there were no statistically significant differences between the toxicity groups as regards any of these indices either in the first period or over the whole duration of the trial. Nor was there even any suggestion that fewer joints narrowed or fewer new erosions developed in the toxic group. On the contrary, in the toxic group of the gold series, $7 \cdot 8$ per cent. of joints not initially narrowed became so in the first 18 months, compared with only $7 \cdot 1$ per cent. for the non-toxic group. Over the whole trial, N 19 per cent. of the possible number narrowed in both the toxic and non-toxic groups. Similarly, the mean number of new erosions per assessable joint was $\omega$ higher $(0 \cdot 18)$ in the toxic than in the non-toxic group $(0 \cdot 16)$ during the first period; and over the 0 whole trial the respective means were 0.32 and 0.23 .

Contrasting the severe and less severe toxic sub-groups, the severe group showed, if anything, 
TABLE VII

RADIOLOGICAL ASSESSMENT AT START OF TRIAL IN THE TOXIC AND NON-TOXIC GROUPS

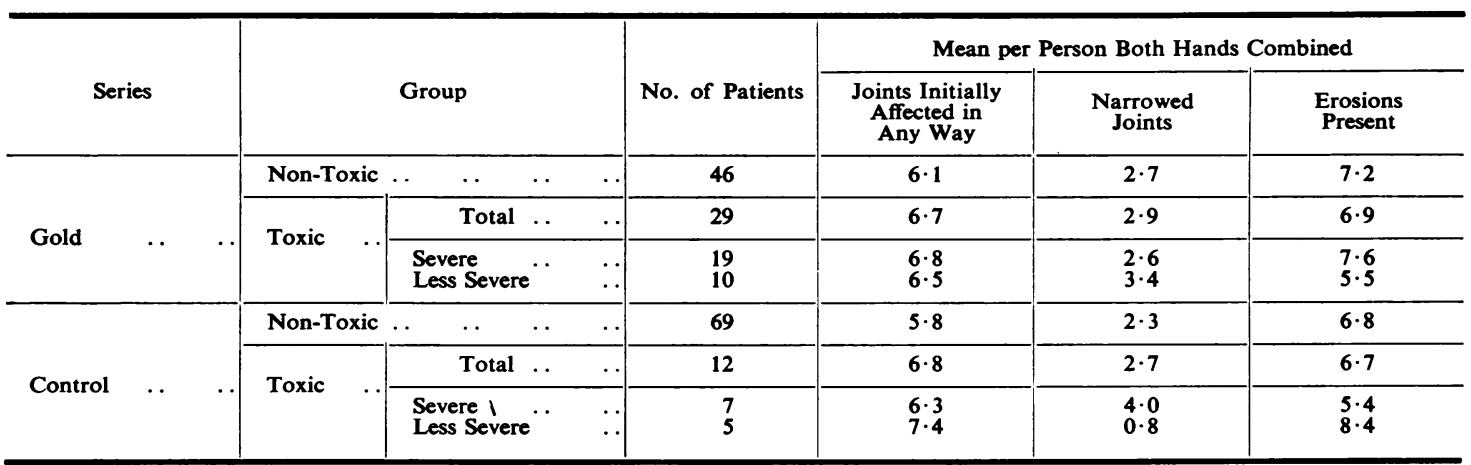

TABLE VIII

RADIOLOGICAL PROGRESSION IN HANDS IN PATIENTS IN THE NON-TOXIC AND TOXIC GROUPS

\begin{tabular}{|c|c|c|c|c|c|c|c|}
\hline \multirow{3}{*}{ Radiological Assessment } & \multirow{3}{*}{\multicolumn{3}{|c|}{ Group }} & \multicolumn{4}{|c|}{ Series } \\
\hline & & & & \multicolumn{2}{|c|}{ Gold } & \multicolumn{2}{|c|}{ Control } \\
\hline & & & & $0-18 \mathrm{mths}$ & $0-30 \mathrm{mths}$ & $0-18 \mathrm{mths}$ & $0-30 \mathrm{mths}$ \\
\hline \multirow{3}{*}{$\begin{array}{l}\text { (a) Joints which Narrowed } \\
\text { (percentage of number which } \\
\text { could narrow) } \ldots\end{array}$} & Non-Toxic .. & $\cdots$ & $\cdots$ & $7 \cdot 1 \pm 1 \cdot 8$ & $19 \cdot 3 \pm 2 \cdot 8$ & $8 \cdot 1 \pm 1 \cdot 2$ & $19 \cdot 1 \pm 2 \cdot 1$ \\
\hline & \multirow[b]{2}{*}{ Toxic } & Total & . & $7 \cdot 8 \pm 3 \cdot 0$ & $18 \cdot 7 \pm 3 \cdot 7$ & $8 \cdot 2 \pm 3 \cdot 3$ & $17 \cdot 2 \pm 5 \cdot 6$ \\
\hline & & $\begin{array}{l}\text { Severe .. } \\
\text { Less severe }\end{array}$ & $\begin{array}{l}\cdots \\
\cdots\end{array}$ & 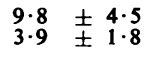 & $\begin{array}{l}20 \cdot 0 \\
16 \cdot 3 \quad \pm 5 \cdot 0\end{array}$ & $\begin{array}{r}10 \cdot 5 \pm 4 \cdot 5 \\
5.0 \pm 5.0\end{array}$ & $\begin{array}{l}19 \cdot 6 \pm 8 \cdot 7 \\
13.8 \pm 6.5\end{array}$ \\
\hline \multirow{3}{*}{$\begin{array}{l}\text { (b) Mean Number of New } \\
\text { Erosions (per assessable joint) }\end{array}$} & Non-Toxic & . & $\cdots$ & $0.16 \pm 0.03$ & $0.23 \pm 0.04$ & $0.20 \pm 0.03$ & $0.33 \pm 0.04$ \\
\hline & \multirow[b]{2}{*}{ Toxic . } & Total & $\cdots$ & $0.18 \pm 0.04$ & $0.32 \pm 0.08$ & $0.25 \pm 0.06$ & $0.42 \pm 0.10$ \\
\hline & & $\begin{array}{l}\text { Severe ... } \\
\text { Less Severe }\end{array}$ & $\begin{array}{l}\cdots \\
\cdots\end{array}$ & $\begin{array}{l}0.19 \pm 0.06 \\
0.15 \pm 0.05\end{array}$ & $\begin{array}{l}0.35 \pm 0.11 \\
0.26 \pm 0.06\end{array}$ & $\begin{array}{l}0.27 \pm 0.09 \\
0.21 \pm 0.10\end{array}$ & $\begin{array}{l}0.42 \pm 0.17 \\
0.41 \pm 0.10\end{array}$ \\
\hline \multirow{3}{*}{$\begin{array}{l}\text { (c) Mean Number of Extensions } \\
\text { of Old Erosions (per assessable } \\
\text { joint) }\end{array}$} & Non-Toxic & $\cdots$ & $0^{\circ}$ & $0.09 \pm 0.02$ & $0.08 \pm 0.02$ & $0.08 \pm 0.01$ & $0.10 \pm 0.02$ \\
\hline & \multirow[b]{2}{*}{ Toxic . } & Total & $\cdots$ & $0.06 \pm 0.02$ & $0.10 \pm 0.03$ & $0.05 \pm 0.02$ & $0.07 \pm 0.03$ \\
\hline & & $\begin{array}{l}\text { Severe ... } \\
\text { Less Severe }\end{array}$ & . & $\begin{array}{l}0.07 \pm 0.03 \\
0.06 \pm 0.03\end{array}$ & $\begin{array}{l}0.11 \pm 0.04 \\
0.09 \pm 0.03\end{array}$ & $\begin{array}{l}0.04 \pm 0.02 \\
0.06 \pm 0.03\end{array}$ & $\begin{array}{l}0.05 \pm 0.03 \\
0.10 \pm 0.05\end{array}$ \\
\hline
\end{tabular}

greater progression of the disease radiologically, but this degree was not greater than could be ascribed to chance.

\section{Discussion}

The two groups of patients, those who developed toxic reactions to gold therapy and those who did not, were in all main essentials comparable at the start of therapy. In the gold-treated series, 68 per cent. of the "toxic" group were initially in the two high grades (Functional Capacity Grades I and II) compared with 59 per cent. of "the non-toxic" group, and the toxic group appeared on the average slightly more "fit", on the patient's own assessment, than the non-toxic group. Nevertheless, not one of the indices used, including the radiological, indicated that those patients who developed toxic reactions fared any better at any stage of the trial than those who did not. Indeed, the evidence tended the other way: the numbers involved were small and most of the differences which emerged were no larger than could be ascribed to chance-but their consistency in favour of the non-toxic patients was a prominent feature throughout. The single statistically significant difference was the greater number of joints affected at Month 12 in the toxic group, a further point of advantage to the non-toxic group.

This trial does not, therefore, confirm the idea previously held by some clinicians that good therapeutic results are usually to be expected where gold salts have produced toxic effects. The evidence, indeed, slightly favours the opposite view. 


\section{Summary and Conclusions}

(1) In the trial of gold therapy in rheumatoid arthritis reported in detail elsewhere in this Journal (Empire Rheumatism Council, 1961), 35 of a series of 99 patients treated with gold and 16 of a series of 100 controls developed toxic reactions, all but one during the course of injections. 77 of the gold series (31 toxic and 46 non-toxic) and 82 of the control series (12 toxic and 70 non-toxic) were followed for 30 months from the start of the trial.

(2) Comparing the clinical progress of those who developed toxic reactions with that of those who did not, no evidence was found that the toxic group fared better than the non-toxic by any of the indices used, including radiological examination. The only significant difference which emerged was that the number of joints involved at Month 12 in the goldtreated series was greater in the toxic than in the non-toxic group.

\section{REFERENCE}

Empire Rheumatism Council (1960). Ann. rheum. Dis., $19,95$.

(1961). Ibid., 20, 315.

Le rapport entre les réactions toxiques au cours de la chrysothérapie et l'amélioration dans l'arthrite rhumatismale

RÉSUMÉ ET CONCLUSIONS

(1) Au cours d'un essai de la chrysothérapie, rapporté ailleurs en détail (Annals, 1960, 19, 95; 1961, 20, 315), 35 malades appartenant à une série de 99 malades traités par des sels d'or et 16 malades d'entre 100 témoins manifestèrent des réactions toxiques. Toutes ces réactions, sauf une, survinrent pendant une série d'injections. Soixante-dix-sept de la série à l'or (31 "toxiques" et 46 "atoxiques") et 82 témoins (12 "toxiques" et 70 "atoxiques") furent surveillés pendant 30 mois dès le commencement de l'essai.

(2) En comparant les progrès des malades ayant accusé des réactions toxiques à ceux des autres on trouve que, selon tous les critères y compris un examen radiologique, les "toxiques" n'allaient pas mieux que les "atoxiques". $\mathrm{La}$ seule différence appréciable fut trouvée dans le nombre des articulations impliquées au bout de 12 mois dans la série des malades traités par des sels d'or; il y en eut plus chez les "toxiques" que chez les "atoxiques".

Relación entre las reacciones tóxicas durante la crisoterapia y las mejorías en la artritis reumatoide

\section{Sumario y CoNClusiones}

(1) Durante una investigación de la crisoterapia, relatada detalladamente en otros artículos (Annals, 1960, or $19,95 ; 1961,20,315), 35$ de una serie de 99 enfermos tratados con sales de oro y 16 de una serie de 100 testigos manifestaron reacciones tóxicas. Todas estas reacciones, menos una, ocurrieron durante una serie de inyecciones. Setenta-y-siete de la serie tratada con oro (31 "tóxicos" y 46 "atóxicos") y 82 de la serie de los testigos (12 "tóxicos" y 70 "atóxicos") fueron seguidos durante 30 meses desde el comienzo de la investigación.

(2) Al comparar el progreso de los enfermos que $\vec{\varphi}$ habían manifestado reacciones tóxicas con los demâs on se observa que, según todos los indicios incluyendo un examen radiológico, los "tóxicos" no se hallaron mejố? que los "atóxicos". La sola diferencia significativa fữ encontrada en la serie tratada con oro en el número de las articulaciones afectas al cabo de doce meses; este número fué mayor en los "tóxicos" que en los demás. 